\title{
A CASE STUDY OF THE “OFFICES” PROJECT (TEACHER-LESS, COOPERATIVE LEARNING GROUPS) AT GRIFFITH UNIVERSITY: IMPLEMENTING EDUCATIONAL THEORY
}

\author{
B DICK, L GODDEN, K HEALY AND MJ LE BRUN WITH G \\ AIRO-FARULLA AND D LAMB*
}

Although articles which discuss new ways to teach and assess students in law programmes are not uncommon in law journals in Australia today, few papers attempt to describe how innovations can be introduced into law curricula. Reputable journals in law or education simply, and rightly, refuse to publish work which lacks a sound educational basis. To achieve an appropriate balance of description, prescription, and theory in academic writing can be difficult. Nevertheless, some law teachers are eager to hear about the implementation of new methods of teaching as they consider introducing similar reforms into their courses by building upon the knowledge and expertise - as well as the mistakes — of the original designers.

In this article, we discuss recent developments in the use of teacher-less, cooperative learning groups by focusing on the "Offices" project, which was introduced and developed by Le Brun into the Griffith University Law curricula in 1992. A framework, outlining the educational theory and rationale that provided the foundation for the conception and ongoing design of Offices, is presented. We, then, review the use of Offices in order to provide some practical guidance to individuals who wish to introduce similar learning opportunities. ${ }^{1}$ 


\section{THE LEARNING/TEACHING PROGRAM AT GRIFFITH UNIVERSITY LAW SCHOOL}

All law students at Griffith University Law School are enrolled in integrated degree programs, a concept pioneered by Sir Zelman Cowen. The planners of the Law School thought that students would gain a better education if the insights of two disciplines could be used for the benefit of each. ${ }^{2}$ To complement this novel approach, an educational program was developed which incorporates current educational theory and practice. ${ }^{3}$ The traditional lecture/tutorial structure was abandoned and an holistic, structured, and thematic approach to education introduced.

In order to address the needs of different learners as well as remedy some of the shortcomings in professional education identified by writers such as Ramsden, Schon, and Boud, ${ }^{4}$ we introduced a range of educational experiences in which student learning was the focus. In addition to large and small group classes, ${ }^{5}$ each law student is required to participate in teacher-less, ${ }^{6}$ cooperative learning groups, called "Offices". 7 The groups are "teacher-less" in the sense that teachers do not attend the Office meetings; however, they do provide significant guidance for the learning which takes place in the groups. The teachers design the overall direction of Offices to ensure that the learning environment of the Offices complements other sections of the law course and they act as overseers of the program. Offices differ from both the more formal tutorial and from small group teaching where peer tutoring takes place. ${ }^{8}$ Since Offices were developed as an integral part of the overall Griffith Law School undergraduate curriculum, ${ }^{9}$ our discussion and observations about the function and success of Offices should be seen against the entire Griffith curriculum as a "backdrop".

\section{The Office Concept}

The Office concept combines, and further develops, ideas introduced at the University of Adelaide and the City University of New York.

In Adelaide Law School, “syndicates” have operated for several years. ${ }^{10}$ They were introduced in Contract Law due, in part, to their success in Constitutional Law. Students enrolled in contract meet in 
teacher-less groups once each fortnight to discuss contract work. Students then answer questions based on leaderless groupwork in contract law seminars. Assessment for the groups is fifteen percent of the total, although this is redeemable on the final examination. By way of contrast, the format of syndicates has varied over the seven years that they have operated in Constitutional Law. Currently, syndicates of students decide when, where, and how frequently such classes will take place. The group work forms the basis for seminar and tutorial preparation. Assessment of syndicate activity is related to the marks allocated for seminar and tutorial performance for the group. Individual students must have "group certification" before they can claim the group mark.

The educational experience at the City University (CUNY) is quite different. About 20 CUNY students and one teacher form one "house". Each house is organised as a law firm so that cognitive content is married in an experiential learning environment with clinical and lawyering skills as part of an overall experiential approach to legal education. ${ }^{11}$

The Office program at Griffith University is designed to provide students with a structured opportunity to develop the skills associated with the graduate professional in law in a teacher-less, relaxed class environment. Although less ambitious - and less costly - than the CUNY Houses, and more group process and skills oriented than Adelaide's syndicates, teacher-less cooperative learning groups in the form of Offices are proving to be a realistic and practicable addition to the more traditional learning experiences offered to law students in Australia to date.

\section{THE RATIONALE FOR OFFICES}

Offices reflect the educational philosophy at Griffith. They provide a forum in which students can situate, and therefore, deepen, their learning at the same time that they begin to develop the various skills which are commonly associated with the graduate professional in law. ${ }^{12}$ Offices are designed to give students the time and opportunity to reflect on their work and that of their peers.

In its initial conception, the Offices project arose as a response to identified deficiencies in the more traditional methods of teaching and learning law. The aims and objectives of the project incorporate some elements of current educational theory on student 
learning and, in particular, the process whereby the undergraduate matures into the graduate professional which begins in Offices. The following section provides further detail on the rationale for the project and the goals of Offices. Obviously, given the formative nature of the project and the continual process of evaluation and redesign that is a feature of the program, many goals have yet to be fully achieved. ${ }^{13}$

\section{REFLECTION IN ACTION: OVERVIEW OF YEARS ONE AND TWO}

Educationists such as Schon ${ }^{14}$ have identified gaps that exist in professional education. Although many law teachers arm their students with considerable subject matter information and expertise, many students who are well-versed in the rules of law are ill-equipped to undertake work in the manner of professionals in their respective disciplines. Instead of encouraging the development of independent, self-motivated, creative, and analytical thinkers who are able to work with others, it appears that some law teachers in Australia continue to employ outdated and simplistic models of education. Worse, some law courses create a competitive climate of student-teacher dependency, which is atypical of professional work. ${ }^{15}$ Moreover, by conceiving of the teaching of law as the transmission of knowledge which itself is classified into tight legal categories, students are ill-equipped to operate in the "indeterminate zones" of practice, which, according to Schon, are common in the professional world.

To illustrate further: rather than consider how their teaching affects student learning, and rather than use assessment as a learning/teaching strategy to measure student understanding of, and ability to work within, a discipline, many law teachers in Australia use three hour, final year examinations to measure the increase in the quantum of information that a student can demonstrate. Yet upon graduation, the very same students are expected to conduct themselves in the manner of the professional, whose success depends upon abilities to assess themselves and their peers and work independently and cooperatively with others.

Offices provide one example of what we believe is an appropriate structure in which to begin the development of 
professional skills, attitudes, and values. They offer a relaxed forum in which students have the opportunity, at least in theory, to reflect more critically and self-consciously on the law and their work as law students. We acknowledge that not all students are prepared to immediately begin this process of critical assessment and professional development. Therefore, the emphasis is upon the gradual inculcation of these faculties over the entire Offices program, which currently extends over the first three years of the Griffith Law course.

The abilities to monitor and assess the work of oneself and one's peers are important for law students. The use of the process of reflection itself, which is central to self and peer assessment and monitoring, emphasises to students the centrality of reflection as both a process for meaningful learning and as a means for self and peer professional growth. The development of these skills of reflection and self and peer assessment takes time and perseverance, ${ }^{16}$ which is why these skills are introduced in the first year of study in the form of student self and peer monitoring.

In year one, in the course Law and Legal Obligations, students meet weekly in Offices. Students draft rules and principles which govern their group at the same time as they learn about social contract theory. Students also begin to develop the skills of cooperation, self and peer assessment, and oral and written communication. In addition, we have found Offices provide an ideal opportunity for first year students to meet and make friends, whom they may consult in later years in their professional work. Some Offices even double as study groups. Moreover, the integration of knowledge of law and another discipline, which is integral to the Griffith degree, begins in the Offices as students discuss readings of interdisciplinary relevance.

In year two, Offices act as a bridge between the courses, Constitutional and Administrative Law, on the one hand, and Associations and Trusts, on the other, and between years one and two of the degree program. In weekly Office meetings in the second year, students further develop their communication skills and abilities to work in groups as they are expected to complete joint projects. The client interviewing and drafting skills introduced in year one are refined, and negotiation skills introduced. Student understanding of group processes, which begins in the first year, is 
supplemented in year two by role plays which require students to work effectively with their Office team as well with other individuals who act in roles as "clients" and other Office participants.

\section{RULES AND CONSTITUTIONS: DEVELOPING, REVIEWING AND REFINING}

In order to improve student learning, Office work is "saturated" with, and enveloped by, the substantive law areas of the curriculum. In this way the dichotomy between subject knowledge and skills development, which is reinforced by separating doctrine and skills, is minimised. By creating a clear link between the theoretical and philosophical discussion of rules and constitutions, and' the practical demonstration of these concepts within Offices in years one and two, students should be able to understand more fully the law and its dynamic.

Central to the idea of Offices is the concept of rules and the process of review and refinement. In year one, the creation, function, and amendment of rules link large group classes and Offices. The concept of rules, and the function of law and rule making in society and in Contract Law are discussed in large groups while in Offices the students formulate a set of rules and principles to govern and guide their work. After reading and discussing articles in law and literature on rules, social contract theory, and the rule of law, each Office group presents their rules to the large group class and describes how their Office considered and drafted rules to govern their work for the academic year. ${ }^{17}$

On three separate occasions after the initial formulation of the rules, considerable time is set aside for students to review and evaluate formally the operation of their rules, the dynamics of their group, and the individual contribution to Offices. Reviews occur at the beginning of the second semester; again in August when staff visit each Office to speak with the students about the general operation of their individual groups; and in the final Office session for the academic year. This process of review, evaluation, and reevaluation is designed so that students are in a position to appreciate the importance of reflection and evaluation in education and in professional life. 
Evaluations of Offices have indicated that many students ${ }^{18}$ felt that the function of Offices rules was not made sufficiently clear to students and consequently the extent which groups referred to rules as a guide to cooperative learning was reduced.

In the second year program, the link between substantive law and Office work begins when students are introduced in large group classes in Constitutional and Administrative Law to the role and functions of a constitution and then asked to draft a constitution for the operation of their individual Offices. This task builds upon the rule making experience in year one Offices and reflects the overall design of the Griffith curriculum in which concepts, themes, and theories introduced in the first year are developed and refined in subsequent years. ${ }^{19}$ As in the first year of study, second year students review their Office work periodically, generally after completing particular segments of work in which they consider what they have gained from their group tasks. In the final session of Offices, students complete a structured evaluation of the operation of the group, consider the effectiveness of Office constitutions overall, and reflect on their personal development as a member of an Office.

This process of review in years one and two is educationally significant for a number of reasons. It mirrors on a small scale the process and dynamics of law and law reform within the wider community. It provides a fruitful basis for discussing issues such as the role and function of rules and principles in guiding and governing human conduct, the notion of obligation, and the nature of law. In Offices, students have an opportunity to consider, and observe "in action", the operation of a "mini legal system" against the background of substantive law.

As the process of review is critical to achieving many of the aims of Offices, there has been considerable refinement in the design of the program to make the aims and objectives more explicit to the students. Evaluations of the early phase of Offices revealed that some students did not appreciate the significance of the review function of Offices. Therefore, we have experimented with a number of methods of review including the use of videotaping, to focus student attention upon this important aspect of Offices.

Moreover, while the theme of rule making provides a coherent 
structure and an integrating link to areas of substantive law, Offices allow students an opportunity to develop communication and interpersonal skills as they begin to reflect more systematically on how they work as members of an educationally oriented group which is not teacher dominated.

\section{COMMUNICATION AND INTERPERSONAL SKILLS, GROUP DYNAMICS, AND RELATIONSHIP BUILDING}

In the past many law teachers have placed considerable emphasis on developing written communication skills in law, some would argue to the neglect of others. ${ }^{20}$ Many legal educators state that the development of skills such as communication and group interaction is antithetical to the notion of university education. This claim, however, ignores how certain skills can be used to enrich, and to assess, student learning. The progress of students who have learned to communicate effectively can be more easily measured if opportunities for class participation are valued and assessed. Furthermore, the assessment of participation appears to motivate some students to work more consistently throughout a term of study, which has considerable educational benefits. It is possible, for example, that deep approaches to learning in law ${ }^{21}$ may require a period of time in which students can sit back, “digest”, and reflect on their learning. Moreover, educational theorists, at least in North America, suggest that students need to be given an opportunity to speak in class at a very early point in law school in order to build the confidence essential for effective oral presentation. ${ }^{22}$

The importance and development of oral skills in Offices is reinforced when students in first year discuss the work of their Offices in front of the large group class. Students, thus, can build on the confidence that they had gained in Offices in preparation for their large group class presentations. In evaluations of Offices students consistently emphasised the value of being given the opportunity to speak in front of the large group class.

Since students meet regularly without a member of the teaching staff present, Offices provide, at least in theory, a less threatening environment for students to talk with one another about law than a more traditional law class. While the absence of teaching staff potentially allows students to work cooperatively to achieve the set 
task the process is not always accomplished without conflict. Evaluations of the project have revealed that particularly in the first year of the project several groups encountered significant interpersonal conflict. The major difficulty identified by students was that some group members sought to dominate group discussions which limited the extent of cooperation within the group. $^{23}$

The extent of interpersonal conflict within Office groups diminished in the second year of the project which may reflect more adequate preparation of the groups in that year. Preparation of the groups included some relationship building exercises, greater attention on the function of Office rules and fuller explanations of the role of Offices in developing cooperative learning and communication skills. It could also be suggested that experience in dealing with interpersonal conflict in order that a group can achieve a set task is a valuable part of a student's progression toward professional attitudes and values.

Offices also foster the development of friendships, and help students to "network" and develop a peer support system. These functions of Offices are most pertinent to first year students where a majority of students (94\%) indicated that Offices were useful in getting to know other students. They also give students a chance to learn to work in groups as part of the process of maturation of the undergraduate to the professional. Considerable assistance in developing these areas of group dynamics was provided in 1993 by a consultant organisational psychologist.

\section{THE ROLE OF THE ORGANISATIONAL PSYCHOLOGIST}

An organisational psychologist ${ }^{24}$ or similar resource person ${ }^{25}$ can assist with the establishment and development of programs such as Offices in three ways: by helping to create an effective group learning environment; by assisting the members of the small groups to work together more effectively; and, by setting up processes for research and ongoing improvement.

A simple way to encourage learning is to adopt adult learning programs such as those described by such writers as Knowles ${ }^{26}$ and Brookfield. $^{27}$ Such strategies, some of which have been incorporated in the design of the Office project, enable students to take responsibility for the type of work that will be expected of 
them as legal professionals. For example, one of the key features of the adult learning approach is the use of learning groups, where students provide mutual support and help one another learn. Organisational psychologists can assist teachers of law in implementing adult learning principles and identifying practical activities which help to integrate understanding and skills.

The way in which a group functions has an impact on its productivity, learning, and enjoyment; organisational psychologists can suggest ways in which groups can examine and improve their own functioning. Much of the success of such group work depends on project design and implementation, particularly because group effectiveness is increased if the groups go through processes in which they build relationships, agree on how they will work together, and define collective goals. ${ }^{28}$

Group work also offers students the chance to improve their social and communication skills, which they will need if they wish to be effective practitioners. Experience alone may prove insufficient, so that explicit skills development is required. Organisational psychologists can help law teachers identify relevant literature that includes some of the more practical activities on such topics as assertion, ${ }^{29}$ effective listening ${ }^{30}$ and conflict resolution. ${ }^{31}$

Although general information on group processes and functioning can shed light on possible areas of improvement in group work such as that undertaken in Offices, designers of educational programs may also need to gain insight into "local issues" 32 - that of the actual, day to day functioning of the Offices. Through the use of action research methods, ${ }^{33}$ organisational psychologists were able to ask the students participating in the Office project to define in their own terms what is effective and what needs improvement. Moreover, involving students in the actual evaluation of Offices is consistent with the philosophy of encouraging professionalism and critical thinking. Clear messages about the role of students in helping make Offices work are given. These messages themselves can improve student commitment to the Offices because students feel that they "own" the project. ${ }^{34}$

\section{THE DAY TO DAY FUNCTIONING OF OFFICES}

In the preceding sections we explored the theoretical framework 
for Offices and outlined the broad aims which guide the project. We now turn to an examination of the day to day functioning of Offices which seeks to realise these aims at the practical level. This examination indicates that theory and practice do not always mesh. Further we emphasise the need to constantly review the operation of the teaching/ learning situation to promote a closer fit between theory and practice.

\section{The Structure of "Offices"}

\section{Group Size}

As educational research emphasises, ${ }^{35}$ students learn effectively, if not best, in small groups. Therefore we endeavoured to keep Office groups as small as possible. Unfortunately, due to timetable and room constraints, between eight-ten students formed each Office at the commencement of the academic year in 1993. As numbers declined slightly over the academic year, the average size was six-seven people. ${ }^{36}$ From our limited experience, it appears that groups became dysfunctional when the number of participants dropped below four, possibly due to the demands of the workload on the group and the pressure of having to report to the large group.

\section{Group Allocation}

Students were allocated to Offices on the basis of their integrated degree only, without regard to age, gender, undergraduate/ post graduate entry, etc., given the difficulties of class schedules. Perhaps not surprisingly, interpersonal conflict amongst some Office members arose in a few groups as we have previously indicated. To further illustrate, we discovered through conversations and questionnaires that some older, usually male, students, who often contributed little to their groups, attempted to dominate some groups. Nevertheless given the philosophy underpinning the Offices, students were encouraged to work through their difficulties within the confines of the group structure, for example, by recourse to the rules that they had formulated for the operation of their Offices. In only one instance did a member of staff become directly involved in a dispute about workload and responsibility for Office work. ${ }^{37}$ 


\section{Office Work}

While the rule making and communication/group dynamics aspects of professional development provide a constant theme for the entire Office program, work for specific weeks is designed to complement the topics covered in large and small group classes. The type of tasks assigned for student attention range from reading and discussing articles to playing roles and interviewing "clients".

In the first year course, in most weeks students read and discuss articles which are selected to help them integrate material from law with the other discipline in which they are enrolled. The materials give students a knowledge base from which to develop skills which form part of the Office program. It emerged from the questionnaires and convergent interviews that some students adopted a "divide and conquer" approach to Office work. When a "divide and conquer" approach is used only one individual within the group reads the article and answers the questions set for that week, often with minimal input from other students in the group. In effect this defeats the cooperative learning function of Offices so teaching staff now endeavour to design tasks which require participation from the entire group.

In year one students also complete a basic introduction to the use of computers. As a result of timetable constraints, this section of the course was scheduled during Office hours. Consequently in 1993 up to four Offices groups were involved in the training course for a three week period, which significantly disrupted the flow of the Office work and caused considerable administrative problems. In 1994 computer classes will be scheduled outside Office hours. In semester one of the second year, students undertook a range of activities including interviewing and advising student "clients", both orally and in writing, in a role play setting. These Office activities centred around partnership and trusts. The second semester program in year two was markedly different. Offices performed different tasks and members took on various roles as part of a joint venture hypothetical which was designed to facilitate integration between law and the other disciplines. Groups created various organisations (eg a joint venture, a public interest group, a regulatory agency), set in train government decision-making processes (including written applications, public hearings, and informal negotiations), made decisions and offered reasons for their 
determinations, and then assessed the validity of those decisions. ${ }^{38}$

\section{Meeting Times}

Students meet in Offices once a week in both year one and year two for fifty minutes immediately prior to their final large group class for the week. This scheduling gives all students the same amount of time within which to prepare their oral and written reports. $^{39}$ One student from each Office or degree stream is required to present a report to the large group during most weeks in year one. ${ }^{40}$ This "report back" gives the teaching staff some insight into the level of work students undertake in Offices; it also provides students with the chance to develop oral communication skills in the context of a large group. In formal evaluations of Office reports, students consistently state that these "reports back" are valuable to the speaker, although many of the students in the large group appear disengaged, particularly if the topic is of marginal interest to them or if the report is dull. In 1994 we will try to engage students in the presentations through a process of peer feedback. ${ }^{41}$

\section{Assessment}

The issue of the formal assessment of Offices remains contentious because Offices have been established to encourage students to take responsibility for their learning and that of their peers. Since no teaching staff meet regularly with the Office members, ${ }^{42}$ considerable creativity from the staff was demanded in the design of assessment. In an ideal situation, one might have thought that students would be happy to participate actively in Offices because of the intrinsic value of learning in a teacherless environment. ${ }^{43}$ However, surveys of student opinion on Offices indicate that students tend to neglect Office work in favour of any assignments and tasks which are assessed. Since many students value what is assessed, and since the Office program is set in the context of other continuous assessment tasks, we decided to measure Office work formally in several ways to encourage students to devote energy to Offices, even though students do receive feedback from a number of other sources.

In year one, members of teaching staff award grades to 
individuals in the Office for reports to the large group classes. ${ }^{44}$ In addition, each Office is expected to submit a brief written response to the assigned task, such as answers to questions or a summary of points discussed. These papers, which are handed back to the Offices with some notes from the teacher, may be profitably used by the students for final examination revision because each student must attempt a question on Office work in the final examination. ${ }^{45}$

In second year, a number of different assessment techniques were used. In most weeks Offices were required to hand in written work on a weekly or fortnightly basis, depending on the complexity of the task. This work was often reviewed by staff and returned with some general comments. ${ }^{46}$ In addition in first semester, videos were made of client interview and advice session role plays. These videos were subsequently reviewed by the Office as a means for students to refine further their self and peer assessment techniques. $^{47}$

The institution of so formal an assessment scheme may appear surprising, in light of the aims of Offices. This judgment must be balanced, however, by the role that self and peer monitoring and assessment play in the overall Griffith curriculum. For example, self and peer monitoring is highlighted in large and small group work in the first year so that students are introduced to the practice early in their law school experience. ${ }^{48}$ In addition, considerable effort is directed toward establishing a climate for learning ${ }^{49}$ so that students will feel comfortable in monitoring their own progress and in commenting upon the work of their peers. These skills are developed further in the second year Offices. Students have the chance to assess their own work in several ways, for example, by reviewing video tapes of their client interviews.

In 1994 we plan to broaden our informal assessment practices by inviting legal practitioners, who have particular interests in the degree programs offered at Griffith Law School, to act as mentors/consultants to Office groups. These practising lawyers will act as role models for students and they will provide feedback to staff on the operation of Offices. We expect that their potential contribution to the future development of the Offices project will be considerable. In order that the maximum benefit be gained from the involvement of legal practitioners it is essential that all mentors become fully consonant with the aims of the project. Accordingly it 
is envisaged that all mentors will be provided with information as to the nature of their role and the most appropriate means of giving feedback to the students and teachers. Legal practitioners are wellplaced to provide feedback particularly in such areas as student performance in the second year client interviewing videos.

Long range yet flexible administration will also be implemented to cope with the "contingencies" that may arise. Given the nature of legal practice such contingencies could include the unavailability of some mentors at short notice.

\section{Attendance as Part of an Assessment Strategy}

In order to emphasise the importance of Offices in the Griffith curriculum, we require all students in years one and two to attend a minimum number of Offices as part of formal assessment. Students in year one must attend a minimum of fifteen Offices over the teaching year to be eligible to sit the final examination. In addition, students receive an attendance grade on a sliding scale of up to five percent of the grade for the year, depending upon the number of Offices attended. Students in year two are ineligible to sit the final examination unless they attend at least seventy five percent of the Offices. No grades are awarded for attendance, however.

As might be expected in teacherless groups, the record of attendance is kept by members of the Office and submitted to the teaching staff at the conclusion of the course. The keeping of the attendance roll has generated conflict within a few of the groups and has raised some ethical issues. We are currently considering ways to deal with unexpected problems such as these in the future..$^{50}$

\section{Evaluation}

As part of good educational practice, and as part of the quality control demands, student performance in Offices is monitored and the operation of the Office program evaluated, which is crucial given the innovative nature of Offices as a method of learning/teaching law. Evaluations of Offices were held formally and informally in 1992 and again in 1993. However, in 1993, a formal evaluation of the project was conducted by a series of convergent interviews, which were carried out by the consultant psychologist to the project as part of the CAUT grant. 


\section{Data Collection and Interpretation}

On the basis of the recommendations of the project consultant psychologists, we chose a convergent interviewing technique ${ }^{51}$ as a major method for data collection and analysis because it allows a diversity of data to be collected within a relatively short time and because the data come from the informants themselves, not from the questions raised by the interviewer/researcher. The technique also includes built-in checks on the quality of data, which is achieved by using information from early interviews to devise more precise questions for later interviews.

In convergent interviewing, the selection of the sample is important to obtain quality information. In this project, 30 students were interviewed, 15 from each year. To ensure that no important information was overlooked, student interviewees (informants) were chosen to maximise diversity of opinion about Offices on the basis of course enrolment, sex, age, and Office group. The sample was compiled by the teachers in the course. Individuals who had expressed considerably different opinions about Offices were also interviewed. The interviewers/researchers consisted of two members of the research team not involved as teaching staff in the Office program and five psychology postgraduates who were particularly familiar with the convergent interviewing method.

An important feature of the convergent interviewing model involves the comparison between different interview results. In the breaks between the individual interviews, the interviewers/researchers consulted notes to ascertain when two or more informants agreed or disagreed about an issue. This process served two purposes: it allowed issues to be identified as having high priority ie where they were mentioned by the students interviewed; and it guided the interviewer in devising more probing questions for later interviews. Probe questions were developed to explain any disagreement and to test any agreement by finding exceptions. The depth of the information provided by the students, therefore, increased from interview to interview. Probe questions were asked only at the end of each interview so that each informant had the same opportunity to define issues without further influence from previous interviews.

Each interview began with the very broad, open-ended question on the subject, "Tell me about Offices...” Interviewers/ researchers 
encouraged informants to talk by giving them considerable attention and by the use of positive verbal and non-verbal signals. A typical interview was completed in one hour.

The outcome of the convergent interviews was a set of issues and ideas which arose from the student informant with almost no direction given from the interviewer/researcher. This information was then provided to the teachers directly involved in the Office project in such a way that the anonymity of individual informants was preserved. The data collected provides considerable insight into how the law students regard the Office programme. It was this information, in combination with the experience of two years of the operation of Offices and the results from student questionnaires, that has provided a most effective foundation for our general review of the Offices project.

\section{RECOMMENDATIONS: WHAT WE HAVE LEARNED}

The Office program has developed considerably since its inception into the Griffith Law curriculum in 1992, no doubt due to the enthusiasm of the staff and many students who were willing to contribute to the development of their education, and the grant which was awarded in 1993. Nevertheless, we are aware that we must give considerable thought to future developments as we begin to learn from our experiments with teacher-less groups in legal education.

Below we list some of the lessons which we have learned in the past two years in implementing Offices, which may be of assistance to individuals who wish to introduce a similar approach to learning.

\section{The Initial Phase: Design}

- Before implementing such an approach to learning, the goals, aims, and objectives of any teacher-less group project should be clear in the minds of all curriculum designers and teachers in the course.

- Students need to understand exactly why the program is being instituted. Transparency of goals, aims, and objectives is imperative if a project of this nature is to be introduced and evaluated. Thus, students should receive detailed information about all aspects of Offices in addition to regular handouts and 
information which describe particular aims and objectives as well as the individual Office task.

- Members of staff involved in the project should be willing to openly acknowledge the diversity of the project's goals so that students appreciate that teacher-less groups offer considerable scope for a different type of learning experience.

- Where possible, the program should be built into the curriculum so that it is consonant with, as well as complements, the overall learning/teaching program.

- If desirable and time constraints allow, consultants should be brought into the design of the project as early as possible. Since much of the 1992 Office program was developed last minute, we were not as well prepared for the concerns that some of the students raised as we might have been. ${ }^{52}$

- If possible, a bank of materials and activities for the use of students and staff should be compiled to help resolve difficulties which students might face so that staff involvement is as limited as possible.

- The skills of self and peer monitoring and assessment and communication skills should be integrated with other aspects of the substantive law curriculum lest the teacher-less group work be seen by students and staff simply as a locus for "skills training” and, thus, marginalised.

- If possible, the groups should be kept small. Aim for four to six students $^{53}$ — and where possible, try to have equal numbers of students in the groups.

- A diverse mix of students in each Office should be considered so that students have a rich environment for debate and discussion. Where possible students should be grouped on the basis of age, gender, etc. We allocate students according to degree stream to encourage integration of subject matter, and to provide a forum for students to meet with one another and exchange ideas about their specific degree programs. It may be beneficial to experiment with different types of groups to determine the best mix.

- To provide a coherent structure, we have found it useful for students to develop some rules/principles for governing/ guiding their groups. To emphasise the importance of reflection in learning and professional development, students should be 
encouraged to review their rules/principles at least twice in an academic course so that they can reflect on and amend them, and still have an opportunity to see how the newer version operates in practice.

- If possible, activities and readings on relationship building, and time within which students can learn to work together should be provided. As part of this process ensure that students have sufficient time to think about and review their work in the group as individuals and as members of a team.

- If timetable constraints 'allow, teacher-less groups in timetable blocks so that all students complete the same task at the same time.

- When possible the work in Offices should be varied. Students seem to like to debate particular areas of interest. Questions should be "controversial", thus allowing scope for a divergence of opinion.

- Offices tasks should be designed so that they can be completed within the time allotted. Operate on the assumption that students are prepared before attending Offices. This may require some adjustment as the project develops.

- Activities should be designed which require group cooperation to complete to avoid the work being delegated to individuals. We have found that reading articles and answering questions per se is particularly conducive to a "divide and conquer approach".

\section{ASSESSMENT AND FEEDBACK}

- Consider instituting some form of assessment procedure to ensure that students take teacher-less work seriously. At the very least, make sure that there is some mechanism by which students can report on the work carried out in their groups.

- Ensure that students receive regular and structured feedback on Office performance so that "'bad habits" do not become entrenched modes of operation.

- Make the experience as "real" as possible so that students appreciate the value of their work and their contributions.

- When in doubt, give guidance generally to the entire class rather than one particular group so that all students feel that they are being given the same direction and attention.

- If legal practitioners are to be invited to contribute as role 
models, make long range, detailed planning arrangements.

\section{EVALUATION}

- Remain open to student comments and observations; they have been our greatest source of feedback on Offices.

- Discuss the personal, social, ethical and professional implications of working within a group. Be willing to speak openly about problems such as bullying (eg on attendance rolls) and unpreparedness within the context of the world of work so that students can see a direct link between what the teacher-less program attempts to achieve and the work of the professional. If need be, inform the students that certain types of activities fall within university regulation and censure so that students appreciate the gravity of certain forms of behaviour.

- Be aware of group dynamics - particularly between school leavers and mature age students, ${ }^{54}$ and between women and men as such sensitivity can defuse many potential conflicts. Discuss issues of gender, race, age, etc openly with the students, when appropriate.

- Be prepared - to experiment, for success, to make mistakes, and to admit the mistakes. ${ }^{55}$ We have met student opposition, intransigence, hostility, as well as receptivity and enthusiasm. Recognise that some students will see the project as an easy grade, if Offices are assessed. Consider ways to overcome this problem. Be ready to sit back while problems are resolved but to intervene in the event of conflicts by providing information, activities, etc.

- Be prepared for the unexpected. The videos showed us one side of the Offices that we did not anticipate.

- Lastly, do not assume that teacherless group activities are resource free. They are not a cheap way of doing more or the same with less, at least at the onset of the program.

\section{PROSPECTS}

The Offices project in years one and two will be revised in light of the information that we have received formally and informally from first and second year students in questionnaires and convergent interviews. 
In the first year, greater attention will be given to "relationship building" exercises, to improving student understanding of the role and function of Offices vis-a-vis contract law and social contract theory, to disseminating more structured information about group processes and dynamics, and to designing activities to help students improve their abilities to work as members of a team and to engage in self and peer monitoring and assessment. In addition, the mentoring/ consultancy aspect of the project will be introduced in 1994.

In year two, there will be greater emphasis on improving feedback to the Offices. This may involve more frequent use of videos and the further development of inter-group activities which require Offices to provide feedback to each other. We will also devote greater attention to designing tasks which require group cooperation and which cannot be completed by one individual, so that the students learn to work effectively as a team. In effect this should provide for a more structured process of self and peer assessment.

The Office project will be extended to the third year curriculum, which will be offered for the first time in $1994 .^{56}$ The program will be designed to integrate the study of the several law subjects studied that year, (Property, Torts, and Revenue Law) with each other, and with the students' other disciplines. New skills elements which will be introduced include crosscultural communication skills and alternative dispute resolution. The use of role plays will be further developed. Office members may act as "clients" in conveyancing, taxation, and tort matters.

\section{CONCLUSION}

Offices, as teacherless, cooperative learning groups, are an initiative which incorporates current educational theory into the actual practice of teaching law. They fulfill a number of aims within the holistic, structured, thematic, and interdisciplinary approach to legal education that is integral to the Griffith curriculum. The particular strengths of the project lie in the opportunities for students to begin the transition from the undergraduate to the graduate professional, to learn the skills of self and peer monitoring and assessment, to be involved and share responsibility as a group member, to extend their understanding of 
the process of rule making in a practical context, to develop as communicators, and to begin the process toward independent, self motivated learning - all within the framework of substantive areas of law.

The Office program has grown in ways not envisaged at the time of its introduction in 1992. The nature of the expansion indicates the potential of Offices to incorporate many, diverse aims and to develop as an innovative form of teaching/ learning. Offices remain at a formative stage. Information that we have received from the various evaluations of the project will form the basis for continual modification and refinement, particularly as Offices are to be introduced into the third year course. Such review is necessary to ensure that Offices continue to meet the challenge of providing a forum for cooperative, teacherless learning.

* Lecturer, Psychology, University of Queensland; Lecturer in Law, Griffith University; Research Assistant, University of Queensland; Senior Lecturer in Law, Griffith University; Lecturer in Law, Griffith University; Research Assistant, Griffith University, respectively.

We would like to thank Charles Sampford, Kevin Nicholson and Rosemary Owens for their assistance. We would like to extend our heartfelt appreciation to students in the Griffith Law School who have been more than helpful with their comments and observations about the Offices project.

This project was funded, in part, by a 1993 National Teaching Development Grant from the Committee for the Advancement of University Teaching, and awarded on the basis of research conducted by $\mathrm{M}$ Le Brun as described in a joint grant application with Charles Sampford.

(C) 1993. (1993) 4 Legal Educ Rev 273.

1 For a fuller picture of the Offices project see B Dick L Godden K Healy \& M Le Brun, The Use of Action Research in Developing Curricula in Law: Convergent Interviews and the "Offices" Project (forthcoming); L Godden \& M Le Brun, Transforming the Undergraduate into the Graduate: Resource Tools for Introducing Teacher-Less Group Work in Law (forthcoming); and L Godden D Lamb \& M Le Brun, The "Offices” Project at Griffith University Law School and the Use of Video in Evaluating Teaching Initiatives (forthcoming).

2 Information on the initial degree structure is contained in Appendix One: The Griffith Law Curriculum (1992) 1 Griffith Law Rev viii. Further information on the current integrated degree programme can be obtained from the Law School, Griffith University, Nathan, Queensland, 4111, Australia.

3 Elements of a humanistic perspective were adopted. For a discussion of humanistic approaches see W Gelhorn, Humanistic Perspective: A Critique (1982) 32 J Legal Educ 99; G Bellow, The Limits of Humanistic Law Teaching (1978) 53 New York U Law Rev 644.

4 Some of the works which influenced the development and refinement of the Griffith curriculum include: P Ramsden, Learning to Teach in Higher Education, (London: Routledge, 1992); D A Schon, Educating the Reflective Practitioner (San Francisco: Jossey-Bass 1987); D Boud, Assessment and the Promotion of Academic Values (1990) 15 Studies in Higher Education no 1 101. See also Boud's other work on self and peer assessment.

5 We refer to classes as "large" and "small” rather than "lecture" and "tutorial" 
because we employ a wide range of teaching methods, of which lecturing is one. Since learning is promoted when students are actively engaged in their study, interactive teaching methods are widely used.

6 In the past we referred to these groups as leaderless rather than "student- led" or "syndicates", because, in some instances, there is no clear student leader and because "syndicates" has too managerial and bureaucratic a ring. Other characterisations of such groups have included self steering seminars: see JD Andrews \& DA Dietz, The Self Steering Seminar (1982) 53 J Higher Educ 552. On the basis of our evaluation we thought a more appropriate label was "teacher-less, cooperative learning groups".

7 Le Brun is responsible for introduction of Offices into the Griffith curriculum as well as the development and refinement of the first year Office program. AiroFarulla and Lamb designed the Office program for the second year course of study.

8 For an examination of peer tutoring in a law course see JH Moust, ML De Volder \& HJ Nuy, Peer Teaching and Higher Level Cognitive Learning Outcomes in Problem Based Learning (1989) 18 Higher Educ 737; KG Collier, Peer-Group Learning in Higher Education: The Development of Higher Order Skills (1980) 5 Studies in Higher Educ 5.

9 The curriculum is described at length in M J Le Brun, Law at Griffith University: The First Year of Study (1992) Griffith Law Rev 15.

10 "Syndicates" were introduced in Constitutional Law by Professor Michael Detmold.

11 For a more detailed summary of the CUNY program and humanistic legal education, see in particular B L Bezdek, The CUNY Law Program: Integration of Doctrine, Practice and Theory in the Preparation of Lawyers (1993) $9 \mathrm{~J}$ Professional Legal Educ 59; H Lesnick, Infinity in a Grain of Sand: The World of Law and Lawyering in Clinical Teaching Implicit in the Law Curriculum (1990) 37 UCLA Law Rev 1157; J Himmelstein et al, Reassessing Law Schooling: The Sterling Forest Group (1978) 53 New York U Law Rev 561; J Himmelstein, Reassessing Law Schooling: An Inquiry into the Application of Humanistic Educational Psychology to the Teaching of Law (1978) 53 New York U Law Rev 514.

12 See JS Brown A Collins \& P Dugid, Situated Cognition and the Culture of Learning (1989) 18 Educational Researcher 32.

13 A more complete evaluation of Offices, incorporating student opinion and comments, will be available following the submission of a final report to the Committee for the Advancement of University Teaching.

14 DA Schon, Educating the Reflective Practitioner (San Francisco: Jossey- Bass, 1987).

15 See K Mack, Bringing Clinical Learning into a Conventional Classroom (1993) 4 Legal Educ Rev 89.

16 SL Rawson \& AL Tyree, Self and Peer Assessment in Legal Education (1989) 1 Legal Educ Rev, 135.

17 In 1993, students read extracts from Golding, The Lord of the Flies, Hobbes, Leviathan, Rawls, A Theory of Justice, Rousseau, The Social Contract, and Twining and Miers, How To Do Things With Rules: A Primer of Interpretation. In 1994 students will also be given a passage from Locke.

18 Fifty percent of students in the 1992 intake made this observation but only nineteen percent of the 1993 intake felt that this objective was not sufficiently clear.

19 See C Sampford \& D Wood, Theoretical Dimensions of Legal Education - A Response to the Pearce Report (1988) 62 Aust Law 132.

20 M Holmes \& J Maxwell, The Use of Role Play and Video in Teaching Communication Skills to Law Students (1987) 5 J Professional Legal Educ 151. 
21 To date we know little of deep and surface approaches to learning by law students although some preliminary work has been done by G Mullins, J Whittle and K Mack at the University of Adelaide on approaches to learning in the context of a student moot program. See, for example, S Wildman, The Classroom climate: Encouraging Student Involvement (1989) 4 Berkeley Women's Law J 326.

Forty percent of 1992 first year students indicated dominance was a problem while only seven percent of 1993 first year students suggested they had difficulties with individuals dominating a group.

Organisational psychologists enable people to work together in units from small groups to organisations in a more satisfying and effective manner.

25 The skills and experience that people have are more important than their particular occupation or specific qualification. Effective resource people have experience in helping groups identify and solve their problems. Such people may have formal training in organisational psychology, process consultancy, community development, educational psychology, social work or education. For simplicity, we will use the term "organisational psychologist" to refer to people with these relevant skills.

M Knowles, The Adult Learner: A Neglected Species 4th ed (Houston: Gulf, 1990).

S Brookfield, Understanding and Facilitating Adult Learning (San Francisco: Jossey Bass, 1986).

See, in particular, B Dick, Helping Groups to be Effective: Skills, Processes and Concepts for Group Facilitation 2nd ed, (Chapel Hill, Queensland: Interchange, 1992); DW Johnson \& FP Johnson, Joining Together: Group Theory and Group Skills 4th ed, (Englewood Cliffs, N J: Prentice Hall, 1991).

29 See S Drury, Assertive Supervision: Building Involved Teamwork (Champagne, Ill: Research Press, 1984).

30 See R Bolton, People Skills: How to Assert Yourself, Listen to Others, and Resolve Conflicts (Brookvale, NSW: Simon and Schuster, 1987).

31 See H Cornelius, \& S Faire, Everyone Can Win: How to Resolve Conflict (Brookvale, NSW: Simon and Schuster, 1989).

32 "Local" issues may include specific problems with course design, assessment, and functioning of individual groups.

33 The use of Action research in improving the Offices is described in B Dick, L Godden, K Healy \& M Le Brun, The Use of Action Research in Developing Curricula in Law: Convergent Interviews and the "Offices" Project (forthcoming).

34 A team at Deakin University have prepared several valuable resource documents. See, in particular, R Carr \& S Kemmis, Becoming Critical: Education Knowledge and Action Research (London: Falmer Press, 1986) and S Kemmis \& R McTaggart (eds) The Action Research Planner (Waurn Ponds, Victoria: Deakin University Press, 1988).

35 D Jacques, Learning in Groups (London: Kogan Page, 1991); W J McKeachie, Research on College Teaching: The Historical Background (1990) 82 Journal of Educational Psychology 189.

36 A group of 3 did exist in 1992 and 1993, however. These students said that they found the work load heavy.

37 In hindsight we wonder whether such interference was the best course of action.

38 This general framework will, however, change as students who are enrolled in newer degree programs enter their second year of study.

39 In 1992 Office times were spread over a three hour time slot, thus giving a potential advantage in the preparation of reports to those students whose group met early. 
The reporters are chosen by lottery so that at least, in theory, each group prepares thoroughly in case a member of their Office might be asked to report to the large group.

41 We recognise that not all students may welcome feedback from their peers and so such feedback will be optional.

Staff in the year one course meet formally with students in their individual Offices once in the academic year to discuss how the individual Offices are proceeding and to handle any concerns or questions the students might have. The visit is time consuming as we were able to visit four Offices at most in any fifty minute period.

43 See D Boud, Assessment and the Promotion of Academic Values (1990) 15 Studies in Higher Educ 101.

44 No reports were made to the large group in year two because the Offices spanned two different law subjects.

45 The compulsory final examination question was added in 1993 to encourage students to take Office work more seriously. Nevertheless, we would much prefer if students contribute irrespective of the existence and weight of assessment.

46 Unfortunately this assessment method caused some problems because the task was often delegated to one Office member, who completed the work with little assistance from the group.

47 For further information on the results of the video evaluation see L Godden D Lamb \& M Le Brun, The Offices Project at Griffith University and the Use of Video in Evaluating Teaching Initiatives (forthcoming).

48 See S Rawson \& AL Tyree, Self and Peer Assessment (1989) 1 Legal Education Review 134.

49 MJ Le Brun, Climates for Learning: Getting Acquainted in the First Year of Study (1989) Australasian Law Teaching Workshop Materials, Sydney, Macquarie University.

50 Some ways around these problems include: holding open discussions with students in large group classes about problems which might arise in Offices and ways in which to handle them; asking students to sign attendance cards which are to be collected when the Office meets; and reconsidering the weight of assessment as the penalty for non-compliance with attendance is severe in the second year programme and may act as an incentive for students to falsify attendance grades.

51 For a more detailed description see B Dick, Convergent Interviewing version 3 (Chapel Hill, Queensland: Interchange, 1990).

52 For example, we did not have readings and activities readily available to help some of the students overcome problems of dominance by some students.

53 Research indicates that six is generally the optimum size for groups. See D Jacques, Learning in Groups (London : Kogan Page, 1991); AK Rice, Learning For Leadership: Interpersonal and Intergroup Relations (London: Tavistock Publications, 1971).

54 It appears that a few mature age students try to dominate school leavers at the beginning of the academic year while some male students use gender politics as a way to abdicate responsibility which they are expected to assume and share as Office members.

55 We are our students' first point of contact with the legal profession. If we wish to model for our students the work of the professional in action, we should consider talking about how we work. Our students should understand that even we professional teachers in law learn regularly from our successes as well as mistakes.

56 The development of the third year program, in particular, will be aided by the award of a 1994 National Teaching Development Grant from the Committee for 
the Advancement of University Teaching to Airo-Farulla. 